\title{
The brown rot fungi of fruit crops (Monilinia spp.): I. Important features of their biology (Review paper)
}

\author{
Holb, I. J. \\ Department of Plant Protection, Centre of Agricultural Sciences, University of Debrecen, \\ 138 Böszörményi St., 4032 Debrecen, Hungary
}

Key words: fruit rot fungi, Monilinia spp.

\section{Introduction}

The fungal genus Monilinia is economically important, since many of its species are troublesome pathogens of fruit trees of the plant family Rosaceae, particularly apples, pears and stone fruits. Some Monilinia spp. also attack ornamental flowering fruit trees, mainly Prumus spp. and several related genera.

Most Monilinia spp. produce dark brown, rotting areas on infected rosaceous tissues. The dark brown discolouration is due to the oxidation of phenolics of the host by polyphenoxidases, probably produced both by the pathogen and the host. Fruit tissue is partially degraded by Monilinia spp. so that some host cells remain among the interwoven hyphae. Water is lost from infected fruits, which shrink and assume a mummified appearance. The dried infected fruit is commonly referred to as a "fruit mummy". The mummified fruits of trees serve as an important survival form and play a vital role in the life cycle of the fungus. The Monilinia genus causes the greatest damage to fruits of pomaceous and drupaceous trees. Their fruits are medium or large and very or quite rich in nutrients and thus provide ideal substrates for the growth of Monilinia spp.

The aim of this review was, first, to outline some of the biological characteristics of the most important brown rot Monilinia species (this review - part one), and second, to describe the epidemiological characteristics of the brown rot fungi and possibilities of disease control against them (review - part two and three).

\section{Causal organisms}

The genus Monilinia belongs to the family Sclerotiniaceae of the Discomycetes, a subdivision of the Ascomycotina. The genus is characterized by the production of conidial and stromatal anamorphs, apothecial ascomata and ascospores (Byrde \& Willets, 1977).

Honey (1936) subdivided the genus of Monilinia spp. into two sections: Junctoriae and Disjunctoriae. In the Disjunctoriae macroconidia in the conidial chain are separated by a smail structure (disjunctor), while in the Junctoriae these structures are absent. Disjunctors are adaptations that bring about fragmentation of conidial chains and facilitate dispersal of spores by wind. The Disjunctoriae group comprise morphologically and physiologically less specialized pathogens than the Junctoriae group (Byrde \& Willets, 1977; Batra, 1991).

In the section of Disjunctoriae, the disjunctor Monilinia species have narrow host ranges (monotrophs, oligotrophs), are of restricted regional distribution and attack immature fruits and leaves (Batra, 1988, 1991). Two important disjunctor species have been reported from eastern Asia. One is Monilinia mali (Tak.) Whetzel, which is a severe pathogen of apple and Japanese crab apple (Malus sieboldii (Regel) Rehder) (Shima, 1936), and the other is Monilinia kusanoi (Tak.) Yamamoto, which attacks several Prunus spp (Harada, 1977). Three important disjunctor species have also been reported from Europe: Monilinia linhartiana (Prill. \& Delacr.) Dennis (= Monilinia cydoniae (Schell.) Whetzel) on quince; Monilinia johnsonii (Ellis \& Everh.) Honey on hawthorn; and Monilinia mespili (Schell.) Whetzel on medlar (Batra, 1991).

In the section of Junctoriae, the nondisjunctor Monilinia species are pathogenic on several hosts (polytrophs), have a relatively wide geographical distribution and normally colonise ripe fruits. They are comparatively unspecialized pathogens. The three old nondisjunctor Monilinia (form genus Monilia) species are: Monilinia fructigena (Aderh. \& Ruhl.) Honey (=Sclerotinia fructigena Aderh. \& Ruhl.); Monilinia laxa (Aderh. \& Ruhl.) Honey (=Sclerotinia laxa Aderh. \& Ruhl.), referred to as European brown rot; and Monilinia fructicola (Wint.) Honey (=Sclerotinia fructicola (Wint.) Rehm), referred to as American brown rot. The term 'brown rot fungi' is a common name referring to these three nondisjunctor species. In earlier studies, the fungus Monilinia cinerea f. sp. mali Wormald (= Monilinia (Sclerotinia) laxa (Aderh. \& Ruhl.) Honey f. sp. mali Wormald sensu Harrison), which causes blossom wilt and canker of apple trees in Europe, was also included in the term "brown rot fungi". However, it is reported that this fungus is rarely seen in the field because of the effectiveness of current control methods (Willetts \& Bullock, 1993), and it has not yet caused serious yield losses in the Eastern- 
European region. Recently, a new brown rot species was found: Monilia polystroma van Leeuwen, which is an Asiatic brown rot fungus closely related to Monilinia fructigena (Van Leeuwen et al. 2002).

In this review, four brown rot species (Monilinia fructigena, M. laxa, M. fructicola and Monilia polystroma) are discussed further.

\section{Taxonomy, nomenclature, identification and detection}

\section{History of taxonomy and nomenclature}

Byrde \& Willetts (1977) gave detailed information about the taxonomy and nomenclature of the three old brown rot fungi. Here, only a short summary is provided on this subject. The first description of the brown rot fungus was made in 1796 when Persoon found fruits of pear, plum and peach infected by a brown rot fungus (Persoon, 1796). He named the fungus Torula fructigena, but after careful examination of the infected material, he changed the name of the fungus into Monilia fructigena. He used this name for the imperfect conidial stage of the fungus. After the first description, several authors have published descriptions of brown rot fungi and they used several generic and species names. For example Kunze \& Schmidt (1817) described the above fungus as Oidium fructigenum. One year later, Ehrenberg (1818) described another brown rot fungus as Oidium laxum. A few years later, Wallroth (1833) distinguished two brown rot fungi in Europe: the species with the buff-coloured pustules was initially called Oospora fructigena and the one producing ash-grey pustules Oospora laxa. Almost twenty years later, Bonorden (1851) found a brown rot fungus on cherries and named it Monilia cinerea. Later, Schröter (1893) proposed the generic name of Sclerotinia for all known brown rot fungi: Sclerotinia fructigena, Sclerotinia laxa and Sclerotinia cinerea. Woronin (1900) presented convincing evidence that Sclerotinia fructigena (Pers.) Schröter and Sclerotinia cinerea (Bon.) Schröter can be distinguished by morphology and physiology of the anamorph stages. Thus, at the beginning of twentieth century, apart from Sclerotinia fructigena, two other brown rot species were thought to be present in Europe Sclerotinia laxa and Sclerotinia cinerea. In 1905, the anamorph-teleomorph connection for these fungi was definitely established by Aderhold \& Ruhland (1905).

The anamorph of a brown rot fungus was also found in the USA by Peck (1881) and he named the fungus Monilia fructigena as Persoon did in 1801. Two years later, Winter (1883) described the perfect stage of this brown rot fungus and he suggested the name Ciboria fructicola. Norton (1902) discovered and described the apothecial stage of this fungus and he called it Sclerotinia fructigena. However, the size of asci and ascospores found for Sclerotinia (Monilia) fructigena (Pers.) Schröter by Aderhold \& Ruhland (1905) differed from the description of the perfect state of brown rot fungus collected in the USA (Norton, 1902). According to Conel (1914), the fungus described by Norton could not be Sclerotinia fructigena Aderh. \& Ruhl., as the American form did not produce buff-coloured pustules, but instead ash-grey ones. The description of the American brown rot was more similar to the earlier found Sclerotinia cinerea, therefore Wormald (1920) proposed the name Sclerotinia cinerea forma americana for the American form. Later, Norton \& Ezekiel (1924) proposed the name Sclerotinia americana for the American form. After the rediscovery of an early description of the perfect stage of American brown rot fungus (Ciboria fructicola Winter), Roberts \& Dunegan (1924) decided that the only correct name for the American form was Sclerotinia fructicola (Wint.) Rehm.

Wormald (1927) came to the conclusion that Sclerotinia laxa and Sclerotinia cinerea were conspecific and therefore, on the basis of priority, the two species became one under the name of Sclerotinia laxa. Consequently, by that time, three brown rot species were known: Sclerotinia fructigena, Sclerotinia laxa and Sclerotinia fructicola. In the study of Honey (1928), the genera of Sclerotinia Fuckel, Ciboria Fuckel and Stromatinia Boud. were deeply discussed and a new genus, Monilinia, was erected, comprising the monilioid species formerly placed in the genus Sclerotinia. He distinguished this new group from the other Sclerotinia species by the nature of the stroma/sclerotial tissue and the type of conidial fructification. The conidial stage within Monilinia is monilioid, macroconidia are arranged as beads on a string. The author declared the above three species to be of the genus Monilinia and named them as Monilinia fructigena (Aderh. \& Ruhl.) Honey, Monilinia laxa (Aderh. \& Ruhl.) Honey, and Monilinia fructicola (Wint.) Honey. Later, Honey (1936) subdivided the group of Monilinia spp. into two sections: Junctoriae and Disjunctoriae as mentioned in the section of "Causal organism".

\section{Identification and detection}

Identification of the three old brown rot fungi has always been based on general colony characteristics, grown on natural agar media (Wormald, 1920; Byrde \& Willetts, 1977). On potato dextrose agar (PDA), M. fructigena is distinct buff-coloured (Rayner, 1970), while $M$. fructicola has a brownish to ash-grey colour. In early studies, it was also shown that mean conidium size of $M$. fructigena was greater than that of $M$. fructicola and M. laxa (Wormald, 1920; Ezekiel, 1924, Hewitt \& Leach, 1939). Moreover, the features of germ tubes sprouting from conidia are also different. $M$. fructicola and $M$. fructigena produce long, straight germ tubes before branching of the germ tube occurs, while in $M$. laxa branching starts close to the conidium (Ezekiel, 1924; Jenkins, 1965a, Schlagbauer \& Holz, 1987). Furthermore, hyphal anastomosis of germinating conidia has been used to separate $M$. fructicola from $M$. laxa. Hyphal anastomosis commonly occurred in $M$. fructicola, whereas it did not occur or was rare in M. laxa (Ogawa \& English, 1954). Because of the occurrence of intermediate colony types, Sonoda et al. (1982a, 1982b) experienced difficulties in separating $M$. fructicola from $M$. laxa on the basis of general colony characteristics. They proposed the use of interaction of cultures to delineate the 
two species. When isolates of both species were grown in one Petri dish filled with oatmeal agar, dark lines appeared at the junctions between $M$. laxa and $M$. fructicola isolates, but not between $M$. laxa isolates. The recently-described new species $M$. polystroma is quite similar to $M$. fructigena in its features. Van Leeuwen et al. (2002) demonstrated that $M$. polystroma produced more stromata and its colony growth rate was higher compared to $M$. fructigena, while the length and width of conidia were greater for M. fructigena.

As outlined above, classification of the brown rot fungi is entirely based on differences in the anamorph Monilia. A thorough comparison of apothecia of $M$. laxa and $M$. fructicola by Harrison (1933), revealed no morphological differences. Batra (1991) also concluded that ascospore shape is variable in the brown rot fungi and is an unsuitable feature for identification or detection.

Differences in soluble proteins and enzymes have also been studied in order to distinguish the brown rot species. The electrophoretic patterns of soluble proteins and several enzymes between isolates of $M$. fructicola and $M$. laxa were compared, and it was found that both species could be readily distinguished with the enzymes arylesterase and acid phosphatase (Penrose et al., 1976). Extracellular cell wall degrading enzymes, such as pectin esterase and polygalacturonase, also proved to be useful in separating the brown rot species (Willetts et al., 1977; Gupta \& Byrde, 1988).

Nowadays, genetic differences among the brown rot species have been exploited for distinguishing the species. Molecular genetic data on the brown rot species have been accumulated with important consequences for quick identification and detection. Quick identification and detection is essential e.g. in M. fructicola which is listed as a quarantine organism for Europe (Van Leeuwen et al., 2002). Recently, species-specific monoclonal antibodies and molecular tools for quick identification have been developed. Fulton \& Brown (1997) developed a set of $M$. fructicolaspecific primers based on the occurrence of a 418-bp groupI intron in the small subunit rDNA, which was absent from M. laxa and M. fructigena. However, Förster \& Adaskeweg (2000) showed that only seven out of $21 \mathrm{M}$. fructicola isolates produced a band of the expected size while using the primer set mentioned. Other primer sets have been developed based on subtle differences in the ITS 1 and ITS 2 region of rDNA (Förster \& Adaskeweg, 2000; Hughes et al., 2000; loos \& Frey, 2000). M. fructicola-specific primers designed from the 3 'end of the ITS 1 region were able to detect the pathogen in fruit tissue with quiescent infections (Förster \& Adaskeweg, 2000). Recently, Ma et al. (2003) developed nested polymerase chain reaction (PCR) assays based on microsatellite regions for detection of $M$. fructicola. The nested PCR primers specific to $M$. fructicola were developed based upon the sequence of a species-specific DNA fragment amplified by microsatellite primer M13. The external and internal primer pairs amplified two different fragments from $M$. fructicola, but not from any other fungal species present in the experimental fruit orchards. The authors stated that the nested PCR assays could detect small numbers of $M$. fiucticola conidia caught on spore-trap tapes.

$M$. fructigena-specific primers are of interest for countries like Australia and the USA where this pathogen is considered a quarantine pest (Chang, 1986). In a preliminary report Hughes et al. (2000) and loos \& Frey (2000) mentioned the successful development of such primers, but gave no sequence data.

The phytosanitary status of $M$. polystroma has not yet been declared. The intense formation of stromata which was observed in vitro as well as in vivo might enhance the survival of the pathogen. These characteristics may lead to a quarantine status of the pathogen in many countries all over world. Therefore, $M$. polystroma-specific primers will be also of interest for several countries. Fulton et al. (1999) and Van Leeuwen et al. (2002) demonstrated that isolates of $M$. polystroma varied by 5 base substitutions in the internal transcribed spacer (ITS) regions 1 and 2 of the ribosomal DNA (rDNA) from $M$. fructigena isolates. Therefore, these genetic segments can be one of the useful tools for distinguishing the two species.

Above results offer possibilities to test the quality of batches of fruit before being put on long-distance transport.

\section{Geographical distribution}

The four species of the brown rot fungi are not uniformly distributed throughout the regions where fruit trees are cultivated. Wormald (1954) made a study on the distribution of the three old species based on a comparison of specimens and on field records. The main feature in the distribution of the three species was the absence of $M$. fructigena in America, Australia and New Zealand and of $M$. fructicola in the Old World.

Making a more detailed literature review on this subject, it can be seen clearly that at the beginning of the twentieth century, $M$. fructigena and $M$. laxa were endemic in Europe and in the Far East in Japan, while $M$. fructicola occurred only in North America and Australia. However, the brown rot species have spread during the last century and they become established in regions where they were not previously known. First, $M$. laxa was introduced to the west coast of the USA (Oregon) (Jackson, 1915) and within 40 years the pathogen had spread northwards and southwards in the Pacific Coast region (Hewitt \& Leach, 1939; Ogawa et al., 1954). In the meantime, the presence of the fungus was reported in the eastern parts of the USA (Wisconsin) (Keitt et al., 1943), and later in New York State (Kable \& Parker, 1963). Until 1962 the only brown rot species was $M$. fructicola in Australia. However, in 1962, M. laxa caused blossom and twig blights on cherry collected in Victoria (Jenkins, 1965a). Within a few years, the fungus spread throughout the continent (Penrose et al., 1976) and it reached New Zealand (Boesewinkel \& Corbin, 1970). For a long time, only $M$. laxa and $M$. fructigena were known to occur in Japan, however, in 1965 M. fructicola also became established (Terui \& Harada, 1966). Nowadays, Japan is the only known place where the four species coexist (Batra, 1991). In the 1970's M. fructigena was found in one 
experimental pear orchard in the Eastern United States (Batra, 1979). The complete orchard was destroyed to eradicate the disease and the fungus is not in the USA as far as is known. Nowadays, with the enormous growth of international trade as well as an increasing movement of persons among countries, it is much easier for an organism to enter a new country or a continent. Although harbors and airports are controlled to avoid the invasion of new plant diseases or pests, sometimes these measures are insufficient and economic losses caused by these agents are often high. In spite of this, $M$. fructicola has not yet been detected in Europe (Corazza et al., 1999), though on numerous occasions the pathogen has been intercepted at ports of entry (Wormald, 1954; Byrde \& Willetts, 1977).

Summing up the literature review on the geographical distribution, it can be stated that $M$. fructigena can be found in all European countries and in the former USSR, Egypt, Morocco, Turkey, Israel, Iran, India, Korea, China and Japan. Recently, the fungus was also detected in Uruguay and Brazil (A.S.S. Basilio, unpublished). M. fructigena is declared a quarantine organism in the USA, Australia and New Zealand (CMI, 1991).

$M$. laxa occurs throughout Europe, except in the most northern areas, and in some regions of the former USSR. It can also be found in Turkey, Israel, Syria, Afghanistan, Manchuria, China, Japan, South Africa, Australia, New Zealand (Dunegan, 1953; English et al., 1969), North America along the Pacific coast (Evans \& Owen, 1941), New York, Michigan and Wisconsin (Cation et al., 1949; Jones \& Sutton, 1984) and in some countries in central and south America - Guatemala, Argentina, Brazil, Chile and Uruguay (English et al., 1967).

M. fructicola is present in north and south America, the Far East (Korea, Taiwan, Japan) Australia, New Zealand, Yemen, Zimbabwe and South Africa (CABI/EPPO, 1997, 1998). $M$. fructicola is declared a quarantine organism in Europe and is included in the EPPO Al list of quarantine organisms for Europe (OEEP/EPPO, 1992; CABI/EPPO, 1997).

$M$. polystroma is known to exist in Japan (van Leeuwen at al., 2002). The occurrence of this fungus is possibly not restricted to Japan, however, it has not yet been reported from any other country. $M$. polystroma has not yet been declared a quarantine organism in any country, but attention should be paid to determine the risk of introduction of the fungus into areas outside Japan.

\section{Host plants}

As mentioned before, the brown rot fungi infect a wide range of species of the sub-families Prunoideae and Pomoideae as well as other species of the Rosaceae family. In this group, several important orchard crops are included which makes these pathogens very important worldwide. Byrde \& Willetts (1977) consider M. fructicola as the most important pathogen of the brown rot species due to the severe losses it has caused in stone fruits, especially peaches, in the USA, Canada and Australia.
Batra (1991) gives a detailed list of the host plants for the three old brown rot species. In this review, only hosts with economic importance will be mentioned.

M. fructicola has more hosts in the Prunoideae than in the Pomoideae. In the first sub-family are included peach (Prunus persica (L.) Batsch), apricot (P. armeniaca L.), plum $(P$. domestica L.), sweet cherry ( $P$. avium L.), sour cherry ( $P$. cerasus L.) and almond ( $P$. dulcis L.). In Pomoideae, it attacks quince (Cydonia oblonga Mill.), apple (Malus domestica Borkh.) and pear (Pyrus communis L.) It may also appear in grapes (Vitis vinifera L.).

$M$. fructigena casues brown rot of fruits particularly on apple (Malus domestica Borkh.), pear (Pyrus communis L.) and quince (Cydonia oblonga Mill.). It may also attack medlar (Eriobotrya japonica (Thunb.) Lindl., peach (Prunus persica (L.) Batsch), apricot (P. armeniaca L.), plum (P. domestica L.), sweet cherry ( $P$. avium L.), sour cherry ( $P$. cerasus L.) hazelnut (Coryllus avellana Hazelaar) and grapes (Vitis vinifera L.).

$M$. laxa seems to have most hosts within stone fruits although it can also attack species of pome fruits. It also attacks apricot $(P$. armeniaca L.), plum ( $P$. domestica L.), sweet cherry ( $P$. avium L.), sour cherry ( $P$. cerasus L.), almond ( $P$. dulcis L.), peach (Prunus persica (L.) Batsch), apple (Malus domestica Borkh.), pear (Pyrus communis L.), medlar (Eriobotrya japonica (Thunb.) and quince (Cydonia oblonga Mill.).

In the case of $M$. polystroma, no detailed study has been made on the host range yet. It is supposed that the host range of the fungus is equivalent to that of $M$. fructigena.

\section{Symptoms}

The brown rot fungi attack a wide range of fruit trees and ornamental plants of the Rosaceae family. They infect different aerial parts of the host plant and cause symptoms such as blossom, twig and leaf blights, stem canker and fruit rot. Table $I$ summarises the symptoms caused by the three old brown rot fungi ( $M$. fructigena, $M$. laxa and $M$. fructicola) on some important commercial fruit crops. $M$. polystroma is not included in the table because its symptoms are very similar to those of $M$. fructigena.

$M$. fructigena is very important in causing brown rot of fruits, mainly in apple, pear and quince and less frequently in stone fruits. It may also be responsible for twig blights and cankers (Batra, 1991). This species does not attack blossoms too often, because conidia are usually produced late in the season (Willetts \& Bullock, 1993). M. laxa is, especially, a pathogen of blossom, shoot and twig causing wilts, blights and cankers of stone fruits. However, it can be also significant as the causal agent of fruit rot in stone fruits. $M$. fructicola causes brown rot on ripening fruits of Prumus species and not so often in pome fruits. It is an important pathogen causing blossom and twig blight and cankers on several hosts (Batra, 1991). As it is mentioned above, the symptoms caused by $M$. polystroma are very similar to those of M. fructigena. Van Leeuwen et al. (2002) and Fulton et al. (1999) demonstrated that clear morphological and genetic differences exist between $M$. polystroma and $M$. fructigena, but biological differences seem insignificant. Under 
Table I Symptoms caused by $M$. fructigena, M. laxa and $M$. fructicola in some important fruit crops

\begin{tabular}{|c|c|c|c|}
\hline Host & M. fructigena & M. fructicola & M. laxa \\
\hline Almond & & Fruit rot; canker; blossom and twig blight & Fruit rot; canker; blossom and twig blight \\
\hline Apple & $\begin{array}{l}\text { Fruit rot (very common and destructive); } \\
\text { black apple; cankers }\end{array}$ & $\begin{array}{l}\text { Fruit rot (not serious); blighting of spurs } \\
\text { (sometimes); black apple (sometimes); } \\
\text { canker }\end{array}$ & $\begin{array}{l}\text { Fruit rot (not too important); black apple } \\
\text { (sometimes); canker; } M \text {. laxa f. mali } \\
\text { causes blossom wilt }\end{array}$ \\
\hline Apricot & Fruit rot (not too significant) & Fruit rot; canker & Fruit rot; blossom and twig blight; canker \\
\hline Sour and sweet cherry & Fruit rot & Blossom blight & Fruit rot; wither tip (rare); blossom blight \\
\hline Peach and nectarine & Fruit rot & $\begin{array}{l}\text { Fruit rot; blossom blight; twig blight; } \\
\text { canker }\end{array}$ & $\begin{array}{l}\text { Fruit rot; blossom blight; twig blight, } \\
\text { canker }\end{array}$ \\
\hline Pear & Fruit rot & Fruit rot & Fruit rot (rare); blossom wilt \\
\hline Plum & Fruit rot & Fruit rot; blossom blight; canker & $\begin{array}{l}\text { Fruit rot; wither tip and spur blight; } \\
\text { blossom and twig blight; canker }\end{array}$ \\
\hline Quince & Fruit rot & Fruit rot (sometimes) & $M$. laxa is rare on quince. \\
\hline
\end{tabular}

After Wormald (1954), Byrde \& Willetts (1977), Willetts \& Bullock (1993) and Glits (2000)

laboratory conditions, lesion growth rate on fruit was higher and stromata formation was more abundant in $M$. polystroma compared with $M$. fructigena for pear cultivar 'Conference' (G.C.M. van Leeuwen \& I.J. Holb, unpublished). Therefore, fruits infected in the field might be colonised faster and more abundant stroma formation might be composed by $M$. polystroma than $M$. fructigena.

\section{Blossom and twig blights}

Blossom blight is the first symptom in spring. Blossom infection appears when macroconidia or ascospores land on and penetrate flowers of susceptible plants. All parts of the flower can serve as a first infection site. The first symptoms are brown lesions on petals, stamens and pistils. If the weather is humid, the infected parts are softened and rotten. In a dry atmosphere, they are discoloured, dry and brittle. The discolouration may extend along the peduncle and to the young fruit (Byrde \& Willetts, 1977). After penetration, mycelium may invade the petals and stamens entirely in a period of 48 hours and spread into the calyx (Weaver, 1950). Later, the fungi may reach the tissue of the spur and consequently, attack other flowers in the cluster. Some infected blossoms fall the ground, but others can remain attached to the tree for long periods and these typical symptoms give a blighting appearance to the infected plant parts. The blossom blight causes reduction in the fruit set and also infection of young fruits, therefore, it decreases yield (Zehr, 1985; Batra, 1991; Benedek et al., 1990, 1993).

Blossom blight is caused by $M$. fructicola and M. laxa. The blight occurs mainly on stone fruits (Weaver, 1950), such as cherry (Wilcox, 1989; Tamm et al., 1995), plum (Schlagbauer \& Holz, 1990 ; Szabó \& Nyéki, 1995), peach (Sutton \& Clayton, 1972), nectarine (Ogawa et al., 1980), apricot and almond (Mix, 1930), however, it can also be present on apple (Sharma \& Kaul, 1987; Szabó \& Nyéki, 1995), pear and quince. A secondary effect of blossom blight is twig infection. When the blossom is infected, the fungus grows from the floral parts through the peduncle into the twigs and, as a consequence, new sources of inoculum are created for future infection. On peduncles, sporulation usually occurs on the fruit abscission surface. Ogawa et al. (1980) noted that blossom infection causes twig blight and partial girdling of the twigs on peach and nectarine. Twig infections may also result from infected cankers and blighted leaf tissue. On blighted twigs sporulation normally appears on abscission scars of leaves and bud scales on the basal section of the twig. In early spring, sporulation from peduncles is the most abundant (Kable, 1965). About 10 days after infection, a gummy exudate may appear on the twig at the base of the diseased blossoms (Weaver, 1950). Ogawa et al. (1980) observed that profuse gumming occurs with extensive twig blight on apricot and plum. The infected twig is usually killed by the invasion of the fungus, however, Mirocha \& Wilson (1961) showed that the infected twig probably dies from a toxin. A typical killed twig with blighted leaves, blossoms and young fruits is shown on sour cherry in Figure 1.

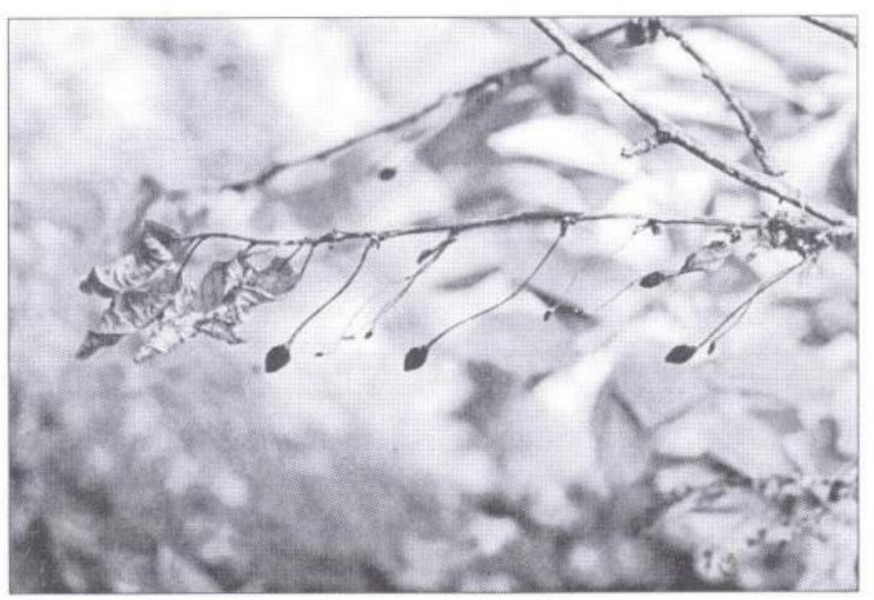

Figure 1 Killed twig with blighted leaves, blossoms and young fruits caused by Monilinia laxa (Aderh. \& Ruhl.) Honey on sour cherry cv. 'Cigánymeggy'. (Photo by $I J$. Holb) 


\section{Leaf blight}

Leaf blight is more common in other Monilinia species belonging to the section of Disjuntoriae. It is rare in $M$. fructicola and $M$. laxa, except from blighted twigs, and it was never found in M. fructigena (Batra, 1991).

Infection of young leaves was reported on plum and cherry, but it was noted that the symptom occurred on plum more often than on cherry. The infection occurs directly through wounds caused by wounding agents such as insect larvae and aphids. A brown discolouration spreads through the leaves until almost the whole lamina is infected. After this, the leaves become shrivelled and show a blighted appearance. The subsequent spread of the fungus into the shoot results in a 'wither tip' symptom (Wormald, 1918, 1954; Drummond, 1934). Spores may develop on infected leaves when the conditions are warm and humid.

\section{Stem canker}

Cankers are necroses of cortical tissues invaded by mycelium. Cankers seldom develop from direct penetration through the external surfaces of the plants. The infection starts from twig and blossom blights or fruit rot. Stem cankers are normally observed on stone fruit species caused by $M$. laxa and $M$. fructicola, while $M$. fructigena has a major importance only on apple.

In the beginning of canker formation, the infected bark dies, tissues beneath the bark become sunken and discoloured and an open wound develops. Often gum is secreted in the diseased area (Ogawa \& English, 1960). Usually, callus tissue develops around the infected area which prevents further growth of the canker. If this is not the case, the wound will continue to grow and extensive damage may be caused. Wormald (1954) observed on apple cultivars 'Melon', 'Cox's Orange Pippin' and 'James Grieve' that a branch girdled by the canker and a part of the branch above the wound died.

If environmental conditions are favourable for sporulation, the fungus can produce conidia on the active canker and therefore, stem canker can serve as a source of inoculum. The pathogen can overwinter in the canker and when spring begins, it can produce conidia in an early phenological stage of the tree. Ogawa \& English (1960) demonstrated that the canker activity increased from winter to spring and wounds could be invaded by secondary pathogens.

\section{Fruit rot}

Fruit rot is one of the most destructive phases in the life cycles of the brown rot fungi. All four brown rot fungi can cause fruit rot in several fruit crops. Fruit infection starts after fruit set and it continues during fruit swelling and ripening. Post-harvest damage is also important. Green fruits are more resistant to infection, and as the fruits are ripening, they become increasingly susceptible (Moore, 1950; Berrie,
1989; Falconi \& Mendegen, 1994; Van Leeuwen et al., 2000; Xu \& Robinson, 2000). It can happen that young green fruits are infected, but symptoms become visible only when the fruits are mature. Batra (1991) and Willetts \& Bullock (1993) demonstrated that the mycelium of $M$. fructicola could remain dormant or quiescent on young fruits until the beginning of fruit maturity and then the fruit becomes infected.

The infection starts with a small, circular and superficial brown spot which progressively increases (Figure 2). At the same time, conidiophores rupture the epidermis of the fruit and form small tufts over the surface (Figures 2 and 3 ). Conidia are formed on sporogenous hyphae. When the conditions are very humid, almost the whole fruit surface is covered with conidial tufts or vegetative mycelium. The entering point of infection is usually a mechanical or physiological injury, particularly wounds caused by insects, frost, birds and other agents (Croxall et al., 1951; Lack, 1989; Van Leeuwen et al., 2000; Xu \& Robinson, 2000). Another common form of injury, especially in apples, is produced when fruits are harvested without their stalks. Within a few days, such apples become rotten around the stalk end, and in the storage they become a source of inoculum for other fruits in contact with them (Wormald, 1954). Byrde \& Willetts (1977) noted that infection often spreads from an infected fruit to healthy ones in the same cluster. Moreover, Michailides \& Morgan (1997) reported that fruit-to-fruit contact is one of the main mechanisms for spread of disease within a tree, and for that injuries are not necessary. Van Leeuwen et al. (2000) supported this hypothesis when they showed that diseased fruits were clearly clustered for cv. 'James Grieve', indicated by highly significant LIP values $(\mathrm{P}=0.01)$. After the infection process, some fruits lose their water content and wrinkled and shrivelled mummies form (Figure 4). This process is referred to as mummification.

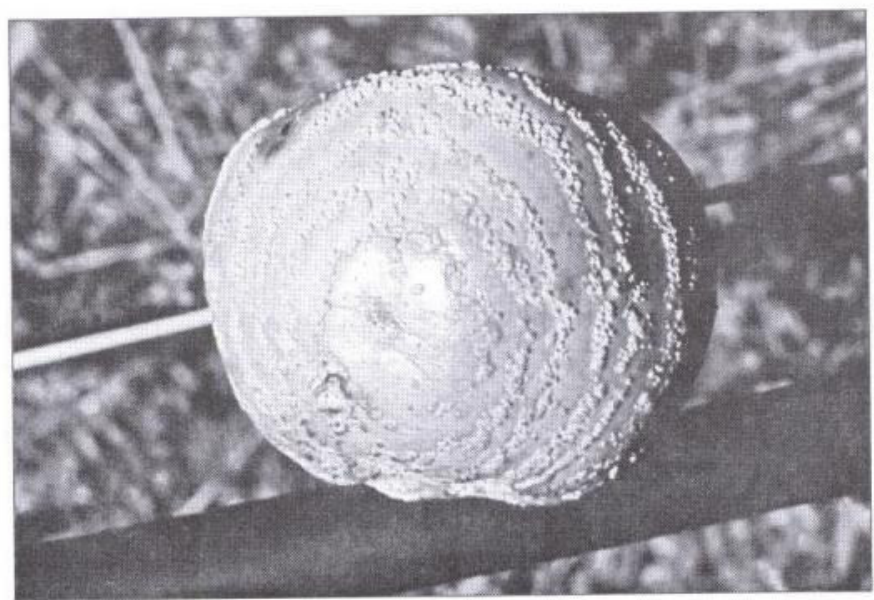

Figure 2 Fruit rot caused by $M$. fructigena (Aderh. \& Ruhl.) Honey on apple. Conidiophores of the fungus rupture the epidermis of the fruit and form concentric rings. Sporodichia are $1 \mathrm{~mm}$ wide and 1-2 $\mathrm{mm}$ high and are classified as 'light-buff' according to the scheme of colours made by Ridgway (1912). (Photo by $I . J .$, Holb) 


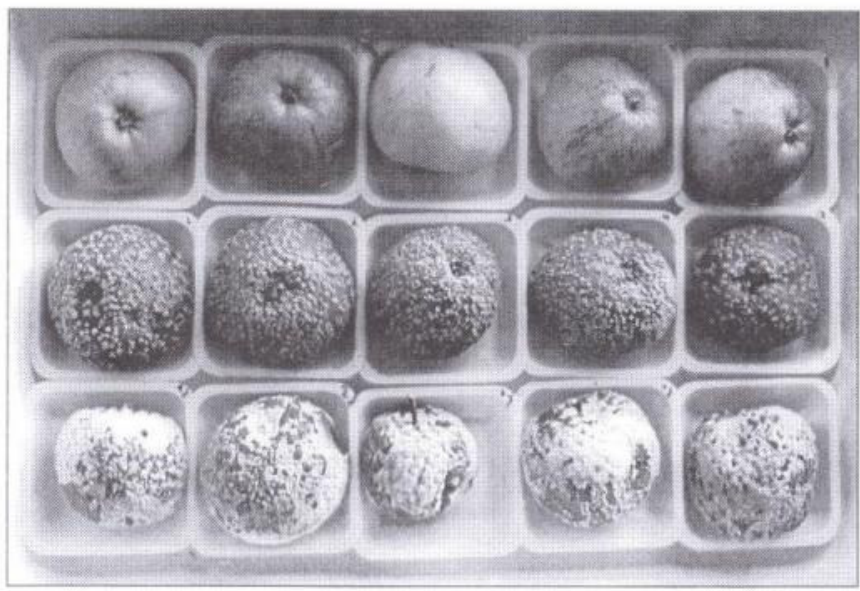

Figure 3 Healthy apple fruits (upper row) and apple fruits inoculated artificially with $M$. fructigena (Aderh. \& Ruhl.) Honey (middle row) and with $M$. polystroma van Leeuwen (lower row) after four-week incubation periods at $20^{\circ} \mathrm{C}$. (Photo by I.J. Holb)

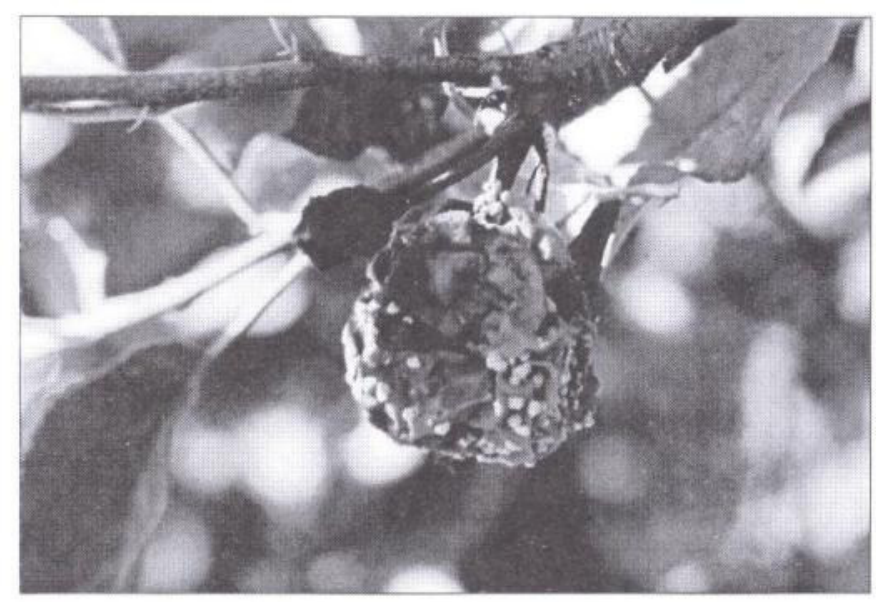

Figure 4 An apple fruit of cv. 'Idared' after the infection process. It has lost its water content and a wrinkled and shrivelled mummy has formed. (Photo by $I . J$., Holb)

A specific type of brown rot is also known as "black apple". This rot commonly occurs on apples in the storage. In the beginning, the color of the infected fruits is brown, but it becomes black during the rotting process. The surface of the black apple is smooth and unruptured by the conidiophores. The rotted fruit has a shiny appearance. In fact, the whole fruit becomes a stromatic mass and the tissues are completely impregnated by mycelium (Wormald, 1954). One of the explanations for inducing the black apple rot type is that complete darkness is not suitable for producing conidiophores by the brown rot fungi, therefore, only mycelium and stromata are developed (Hall, 1933; Wormald, 1954; Byrde \& Willetts, 1977).

\section{Structure and morphology}

\section{Hypha and mycelium}

The hypha of the brown rot fungi is similar to other genera of Ascomycota. Centripetal septa develop at regular intervals along the hypha. Many nuclei may be found in hyphal cells and there are even more in actively growing hyphae. Cells in the aerial mycelium have 20 to 30 nuclei (Byrde \& Willetts, 1977). According to Hall (1933), there are four chromosomes in each nucleus. Hyphal walls and cytoplasm in infected tissues may be hyaline to variously pigmented from light grey to olive green or almost black in stromatal tissues (Batra, 1991). During the germination of conidia, the germ tube of $M$. laxa quickly becomes strongly curved (geniculated) and branches. Some branches can form a partial or complete hoop (Batra, 1991). In the early stages, $M$. fructicola produces straighter and less branched germ tubes and in $M$. fructigena the germ tube grows longer before it starts branching (Ezekiel, 1924; Jenkins, 1965b, Schlagbauer \& Holz, 1987).

Hyphal anastomoses can happen in the brown rot species. They commonly occur in $M$. fructicola, whereas they are lacking or rare in M. laxa (Ogawa \& English, 1954). Also tip-to-tip and tip-to-lateral hyphal fusions are observed. After hyphal fusion, nuclear migration between mycelia occurs and when different mycelia are involved, heterokaryosis may happen (Batra, 1991).

Microscope work showed that hyphae grew intercellularly in the middle lamellae between cell walls as well as intracellularly in the space between host cell walls and the collapsed host protoplast (Calonge et al., 1969; Byrde \& Willetts, 1977). Hyphal colonisation on pear fruits by $M$. fructigena seems to involve three different types of hyphae which showed differences in size, ultrastructure, and function (Najim \& Turian, 1979, Pring et al., 1981). One type of hyphae (about $7 \mu \mathrm{m}$ in diameter) is similar in size to the vegetative hyphae and grows between cells and intercellular spaces. The lomasomes of this hypha produce enzymes that diffuse ahead of the hypha, bringing about dissolution of the middle lamella, therefore, these hyphae are believed to be the first to colonize the host tissue. The second type of hypha (16-20 $\mu \mathrm{m}$ in diameter) grows intercellularly in the colonised regions. This type of hypha is the most common in the infected fruits before mummification. They have a storage function as their cytoplasm contains numerous large vacuoles. The third type of hypha is the smallest, only 3 to $5 \mu \mathrm{m}$ in width and arise as branches from the largest hyphae. The ultrastructure of these hyphae indicated that they had high metabolic activity and they may serve to absorb nutrients.

The initial coloniser hyphae appear to have an enzyme secreting function. These enzymes are responsible for host tissue degradation and liberation of nutrients into the infection site. These nutrients are then absorbed by the fungus and used for mycelial growth. After this, large hyphae develop and produce a compact stroma that takes the shape of the fruit. The large hyphae and their numerous branches possess high metabolic activity, maybe their cell membranes are associated with nutrient uptake from the infection court. During the early stages of stroma differentiation, most nutrients are utilised for mycelial 
growth. But after that, surplus nutrients are deposited in large hyphae that have a structural and storage function in mature stromata (Willetts \& Bullock, 1993).

On agar plates, but also on infected fruits, one of the most common characteristics of the brown rot fungi is the alternation of bands of sterile mycelium with bands of sporogenous hyphae. This characteristic gives zonation across the plates or over the fruit surface. Several factors influence the zonation such as light, nutrient status of the substratum and $\mathrm{H}$-ion concentration of the medium. Another important feature of the brown rot species is the development of plectenchyma in or on the surface of the substratum (Byrde \& Willetts, 1977). When the culture starts to mature, the plectenchyma becomes darkly pigmented and a stromatic plate or small discrete stromata are produced (Figure 5).

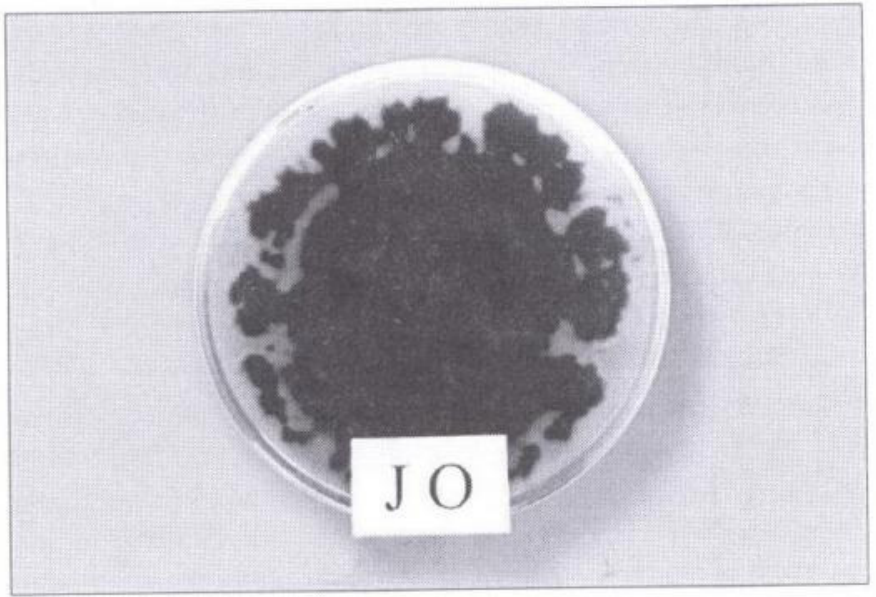

Figure $5 \mathrm{In}$ vitro formation of mature, discrete and black pigmented stromata of Monilia polystroma van Leeuwen on agar plate (PDA media) (Photo by I.J. Holb)

\section{Stroma}

The development of stroma characterises all members of the Sclerotiniaceae family in which the brown rot fungi are included (Willetts, 1997).

It is difficult to distinguish between a sclerotium and a substratal stroma and normally they have a similar response to different factors. Whetzel (1945) described the sclerotium (or sclerotial stroma) as being composed only of hyphal material while the substratal stroma had a medulla formed from a network of hyphae enclosing parts of the host or substrate which serves as a food reserve. Due to the presence of host elements in the stromata medulla of the brown rot fungi, some workers (Aderhold \& Ruhland, 1905; Honey, 1928) classified it as a substratal stroma or pseudosclerotia. It is thought that these elements probably provide supplementary nutrients for later renewed growth (Batra, 1991).

Stromata are very important structures for the pathogens because they may either serve as vegetative reproductive bodies, or may produce sexual or asexual reproductive structures. On the other hand, they are able to overwinter for long periods.
Some authors differentiate ectostroma and entostroma within the substratal stroma. Ectostroma is a small and nondifferentiated aggregation of hyphae that bears conidia. The ectostroma tissue erupts through the surface of host tissues to facilitate spore production and dispersal. Entostroma is a larger well-differentiated tissue that develops as a result of extensive vegetative growth. The entostroma may germinate and produce apothecia, conidia and/or mycelia. Depending on the host and on the pathogen it may develop subepidermally or in the pericarp (Batra, 1991; Willetts \& Bullock, 1993).

Willetts (1968a, b) observed that the development rate of stromata varied strongly and that the formation of mature stromata depended on factors which influenced the growth rate. A prerequisite for stroma formation is the abundance of hyphae. Stromata are considered mature when the stroma develops pigmentation (Figure 5) (Willetts, 1968a). This pigmentation appears due to the accumulation of oxidised phenolic substances or melanin in walls between cells and over the outer surface. The melanin pigments provide protection against harmful solar radiations and against the action of enzymes produced by antagonistic microorganisms (Willetts \& Bullock, 1993).

In culture, the stromata of the brown rot fungi are dark brown to black and may completely fill the Petri dish or appear as small areas in the medium (Willetts, 1968c). Willetts \& Harada (1984) obtained morphologically fullydeveloped stromata in culture or on fruit tissues, at 15 to $20{ }^{\circ} \mathrm{C}$ in a period of 4 to 8 weeks.

The brown rot species show differences in the stroma formation depending how the vegetative mycelium grows, and it appears to be much slower in $M$. fructigena than in $M$. fructicola and $M$. laxa. According to Willetts \& Bullock (1993), stromata of $M$. fructicola are normally bigger and better developed than those of $M$. fructicola and $M$. laxa, often forming a complete hollow-sphere around the seed of the infected fruit. In the case of $M$. polystroma, large amounts of stromata were observed and this feature was one of the basic points for distinguishing it from $M$. fructigena (Van Leeuwen et al., 2002). The available data on the formation of pseudosclerotia suggest that these are formed under conditions that favour mycelial growth, but their water and nutrient requirements are greater than those of the minimum needed for mycelial growth (Hawker, 1957).

Willetts (1969b) noted that there are different requirements for stromata formation and macroconidia production. The different requirements of stroma and conidia are probably related to their structures and their different functions of survival and dispersion that they respectively have. According to Willetts \& Harada (1984) high relative humidity is required for a good stromatal development, because under these conditions sporulation is inhibited.

\section{Macroconidium}

The conidia, also called macroconidia, are of the monilioid type, because they are arranged as beads on a 
string, and they represent the main disseminating units of the brown rot fungi. Macroconidia are elongated to ellipsoid or with a lemon shape. They are sub-hyaline but when in a mass, they can acquire different colours, depending on the species. On average, conidia contain seven nuclei per spore. Normally, macroconidia of $M$. fructigena are bigger than those of the other two species (Table 2). Nevertheless, conidium size alone is not considered a useful character in differentiating the species of brown rot fungi (Byrde \& Willetts, 1977; Batra, 1991). M. laxa can also sporulate during winter and early spring, but conidia are smaller than those produced in summer.

The formation of conidia is holoblastic, which means that conidia are formed by the budding of the terminal part of the surface infected tissues, consisting of numerous short conidiophores bearing long chains of conidia. The conidiophores are similar in appearance to vegetative hyphae and normally consist of two or three rectangular cells. The first step of spore initiation is a thickening of the wall over the apex of the mother cell. The plasmalemma of the mother cell becomes wrinkled probably due to an increase in its length. A bud is formed by stretching of the cell wall and the plasmalemma. It develops at the distal end of a conidiophore and is more ovoid in shape than its mother cell. The bud grows until it is about $10 \mu \mathrm{m}$ long and another bud is formed at its tip. The original bud continues to grow until it has the size of a mature spore. This process continues until ten or more buds are formed (Willetts \& Calonge, 1969). The formation of septa may happen soon after the bud is produced or a chain of young spores may be formed before this process occurs.

Branched chains of conidia are commonly produced. The branches arise from a triangular bud, which produces two outgrowths, each of them giving rise to a new branch. Extra branching may occur after and, consequently, many spores are produced from a single conidiophore. The conidia placed at the distal end are normally the first to be disseminated. If the spore chain breaks in the middle, a segment of several macroconidia may be released as a multiple propagule. Dry conditions favour spore liberation, because they cause shrinking followed by rupture of the primary wall. This wall is continuous along the spore chain and its rupturing is an obligate process for spore liberation (Byrde \& Willetts, 1977).

The pustules form around the site of infection, but their characteristics differ between the three species. In $M$. fructicola sporodichia are $0.50-0.75 \mathrm{~mm}$ wide and up to 1 mm high and 'light drab' or 'mouse grey' on Ridgway's scheme of colours, depending on the stage of maturity (Ridgway, 1912). The size of M. laxa sporodichia is the same as that of $M$. fructicola and they are 'smoke-grey' in colour. In M. fructigena pustules form concentric rings and sporodichia are $1 \mathrm{~mm}$ wide and $1-2 \mathrm{~mm}$ high and they are classified as 'light-buff' on the same scheme of colours.

$M$. fructicola produces most spores in darkness, but $M$. fructigena performs better in light. M. laxa sporulates better in light but at $10{ }^{\circ} \mathrm{C}$ rather than at $15{ }^{\circ} \mathrm{C}$ or $20^{\circ} \mathrm{C}$. The optimum temperatures for sporulation are $10{ }^{\circ} \mathrm{C}, 15^{\circ} \mathrm{C}$, and $20{ }^{\circ} \mathrm{C}$ for $M$. laxa, M. fructigena, and M. fructicola, respectively (Harada, 1977).

\section{Microconidium}

Microconidia differ substantially in form and function from macroconidia. They are spherical bodies to slightly pear-shaped with $2.0-4.5 \mu \mathrm{m}$ in diameter (Wormald, 1954). They are borne on microconidiophores which are dichotomously branched hyphae of 2.5-3.0 $\mu \mathrm{m}$ diameter. The septate branches terminate in bottle shaped phialides on which apices of the microspores are cut off in succession. In the beginning, the microconidium is slightly pear-shaped and normally remains attached to the phialide until another spore begins to form (Willetts \& Calonge, 1969).

The microspore has a fairly simple internal structure. It has a large central body containing lipid material that can occupy half the volume of the spore. This body probably operates as a food reserve. Each spore contains a large nucleus. The microconidium has limited metabolic activity, which can partly explain its inability to produce mycelium (Byrde \& Willetts, 1977).

Table 2 Macroconidia dimensions of the brown rot fungi ( $\mu \mathrm{m})$

\begin{tabular}{|c|c|c|c|c|}
\hline & M. fructigena & M. laxa & M. fructicola & M. polystroma \\
\hline Batra, 1991 & $\begin{array}{l}12-25 \times 12-16 \\
\text { mode } 21 \times 14\end{array}$ & $\begin{array}{l}\text { Summer conidia } 12-18(-24) \times 9-10(-12) \\
\text { Winter conidia are } 0.6 \text { to } 1 \text { times those } \\
\text { formed during summer }\end{array}$ & $\begin{array}{c}10-25 \times 8-20 \\
\text { mode } 14-16 \times 9-11.5\end{array}$ & - \\
\hline Wormald, 1954 & $\begin{array}{l}12-34 \times 9-15 \\
\text { mode about } 22 \times 13\end{array}$ & $\begin{array}{l}\text { Winter conidia } 8-23 \times 7-16 \\
\text { mode about } 11.5 \times 8 \\
\text { Summer conidia } 8-23 \times 7-16 \\
\text { mode about } 19 \times 13.5\end{array}$ & $\begin{array}{l}10-27 \times 7-17 \\
\text { mode about } 15 \times 11\end{array}$ & - \\
\hline $\begin{array}{l}\text { Ezekiel, } 1924 \\
\text { van Leeuwen et al., } 2002\end{array}$ & $\begin{array}{c}\text { av. } 18-18.9 \times 11.4-11.7 \\
17.7-20.6 \times 10.3-12.3 \\
\text { mean } 19.2 \times 11.3\end{array}$ & $\begin{array}{c}\text { av. } 12.9-14.5 \times 9.0-11.0 \\
11.2-12.8 \times 8.2-9.3 \\
\text { mean } 12.0 \times 8.7\end{array}$ & $\begin{array}{c}\text { av. } 14.5-14.9 \times 10.6-10.8 \\
12.4-14.4 \times 8.1-9.9 \\
\text { mean } 13.1 \times 9.1\end{array}$ & $\begin{array}{c}12.8-17.1 \times 8.8-10.7 \\
\text { mean } 15.9 \times 9.8\end{array}$ \\
\hline
\end{tabular}

(adapted from Ezekiel (1924), Wormald (1954), Batra (1991) and Van Leetwen et al., (2002)) 
Some authors noticed that all brown rot fungi produced microconidia in abundance on the surfaces of mummified fruits (Humphrey, 1893; Heuberger, 1934). Their function has been subject of discussion by many investigators. Willetts (1968a) suggested that the microconidia of $M$. fructicola may be functional spermatia and that spermatization of apothecial initials is necessary before apothecia can develop. However, little experimental work has been done in this field (Wormald, 1954; Byrde \& Willetts, 1977; Batra, 1991). Willetts (1968a) also found that initiation of microconidia happens when the substrate is low in nutrients or when growth is inhibited for some other reason, such as when stalin becomes apparent. At the edges or on the surface of the black rings, conditions would be suitable for the formation of microconidia and they were usually found in these positions (Willetts, 1969a).

\section{Apothecium and ascospore}

The apothecium is the fruiting body of the three old brown rot fungi. In the case of $M$. polystroma, because of uncertainties and no teleomorphic material being available to serve as type, the teleomorphic material has not been described yet (Van Leeuwen et al., 2002). However, it is likely that the description of a teleomorph in material from Japan given by Batra \& Harada (1986) and designated as Monilinia fructigena is an account of the teleomorph of Monilia fructigena. The description of the teleomorph given by Batra \& Harada (1986), did not differ from those of apothecia of Monilia fructigena found in Europe (Aderhold \& Ruhland, 1905; Johansen, 1945). Apothecium is a stalked brown cup or disk growing out of a mummified fruit, which has overwintered in the ground (Ezekiel, 1921; Norton et al. 1923). The number of apothecia produced depends on the size of the stromatized tissue or mummy (Willetts \& Harada, 1984) but normally no more than 25 fully developed apothecia appear on one mummy under natural conditions (Wormald, 1954).

$M$. fructigena and $M$. laxa rarely form apothecia, however, the abundant development of apothecia is common for M. fructicola. Willetts \& Harada (1984), in their overview about apothecial production in Monilinia spp., presented an explanation for the rare formation of apothecia in $M$. laxa and $M$. fructigena. The brown rot fungi stromatize mainly ripe fruits like apples, pears, peaches and quinces. These ripen late in the growing season and temperatures during late autumn are too low to permit stromata to mature. Consequently, apothecia will not be produced until the second spring after infection. Such a long period in the soil, where apothecia develop, will increase the probability of microbial lysis or the destruction by other agents. In contrast, $M$. fructicola also attacks other fruits that ripen earlier in the season, such as cherries, apricots and plums and this would allow apothecial production in the next spring following infection. Nevertheless, the rare formation of apothecia by $M$. laxa and $M$. fructigena and the abundant development of apothecia of $M$. fructicola suggest that a number of exact conditions must be fulfilled before apothecia formation takes place. Willetts (1969b) suggested that the failure of apothecial development may be explained due to the poor synchronisation of the production of microconidia and receptive bodies or the lack of contact between them. Willetts (1968d) supposed that apothecial formation may be favoured by the development of a hyphal mat over the surface of the mummified fruit due to greater number of microconidia found in the cavity between the outer surface of the mummified fruit and the inner surface of the hyphal mat.

Apothecial initials develop in the medulla of the stroma. In the beginning, they appear as small nests of hyphae that increase in size by the active division of hyphae to form primordia. One can observe on the surface of the stroma the initials as small, black, shiny protuberances (about $0.5 \mathrm{~mm}$ diameter). After this, the initial ruptures the stromatal rind and the young stripe emerges. At first, the stripe is pointed at its tip but after a while it becomes round and a small depression develops on the upper surface. The head becomes a campanulate (bell-shaped) disc and then it changes to a cup-shaped. On the upper surface, a hymenium develops composed of asci, each containing eight ascospores and sterile paraphyses. When the apothecium is mature, the hymenium is exposed (Byrde \& Willetts, 1977).

The form of the apothecium is similar in all three species (Wormald, 1954). The mature apothecium varies greatly in size depending upon environmental conditions and on the amount of nutrients available. When fully differentiated, the disc or head normally measures $1.0-1.5 \mathrm{~cm}$ in diameter. At first, the hymenium is light-brown to buff in colour but at maturity it is almost white. In the field, when the relative humidity is high, the discs of mature apothecia of $M$. fructicola are usually fully expanded, what gives the characteristic disc-like appearance and maximum exposure of the hymenium to the atmosphere. But under dry conditions, the disc becomes cup-shaped as a way to reduce water loss from the fertile elements of the fruit body. In the hymenium, the asci are interspersed with paraphyses that are simple or with one to three branches of septate hyphae. The paraphyses probably function as a nutrient storage site, because when young they possess protoplasm and protein granules that disappear with apothecium maturation (Batra, 1991). Before the discharge of ascospores, the asci and paraphyses are approximately the same size.

The ascus is a cylindrical sac containing eight, ellipsoid to ovoid, one-celled hyaline ascospores. When the asci are ripe, the sexual spores are ejected. Dimensions of asci and ascospores of the brown rot fungi are presented in Table 3. In $M$. fructigena, asci are tapered at one or at both ends but not pointed, while in $M$. fructicola the ends are normally rounded (Wormald, 1954; Batra, 1991).

Ezekiel (1924) thought that $M$. fructicola was a homotallic fungus due to the development of apothecia from fruits inoculated with a single spore. However, in the recent work of Free et al. (1996) all apothecia of this pathogen 
Table 3 Dimensions of asci and ascospores of the brown rot fungi ( $\mu \mathrm{m})$

\begin{tabular}{|l|c|c|c|c|}
\hline & \multicolumn{2}{|c|}{ Asci $(\mu \mathrm{mm})$} & Ascospores $(\boldsymbol{\mu m})$ \\
\hline & Wormald, 1954 & Batra, 1991 & Wormald, 1954 \\
\hline M. fructigena & $112-180 \times 9-12$ & $160-180(200) \times 9-11.5$ & $9-12.5 \times 5-6.8$ \\
\hline M. laxa & $121-188 \times 7.5-11.8$ & - & $7-19 \times 4.5-8.5$ \\
\hline M. fructicola & $102-215 \times 6-13$ & $(125) 140-150(205)$ & - \\
& & $\times(8) 10-11$ & $6-15 \times 4-8.2$ \\
\hline
\end{tabular}

(adapted from Wormald (1954) and Batra (1991)

found in the field resulted from the outcrossing of different isolates. These results may lead to the conclusion that $M$. fructicola has a heterothallic mating strategy as other members of the Sclerotiniaceae family.

\section{Cultural (in vitro) characteristics}

This parameter is often used to distinguish the species of the brown rot fungi. However, as the pathogens are rarely found in the same region, only a few comparative studies have been made. On the other hand, there is a lot of variation between isolates of the same species, which makes the identification more difficult (Byrde \& Willletts, 1977; Van Leeuwen \& Van Kesteren, 1998).

The most important cultural characteristics of the brown rot species are the colony growth rate, colony form, colony elevation and its margins, texture and intensity of pigmentation, the production mode of stromata and the zonation around the inoculum plug, i.e. alternating bands of sporogenous and non-fertile tissue.

The pathogens grow well in pure culture on prune agar, potato dextrose agar and Brown's medium (Wormald, 1954). On potato dextrose agar the colonies of the three species are filamentous and the aerial growth is cottony (Batra, 1991). The margins of the colonies of $M$. fructigena and $M$. fructicola are entire while in $M$. laxa they are lobed. $M$. laxa can be distinguished from the other two species Via this difference. $M$. fructicola often forms concentric rings of conidiophores where the conidia are abundant in dark or light/dark cycle. These rings are not so frequently observed in M. fructigena. In M. laxa there is a sparse development of conidia over the surface of the colony and the mycelium sometimes becomes pigmented in the centre of the colonies (Byrde \& Willetts, 1977).

The organised stromata are not often produced in $M$. laxa. In $M$. fructigena, the production of these structures is also irregular, appearing especially in dark conditions, while in $M$. fructicola it is more common, mainly in light/dark regime. In this species, the stroma formation may occur on the whole or, more often, beneath the sporulating areas of the colony. According to Willetts (1969b) the three species produce conidial and stromatal areas when incubated under diurnal illumination or continuous light on rich media (e.g. PDA supplemented with $2 \%$ peptone and/or a suitable carbohydrate). $M$. fructicola produce both structures as well when grown in complete darkness.
Recently, cultural characteristis of the four brown rot fungi were re-examined (Van Leeuwen \& Van Kesteren, 1998; Van Leeuwen et al., 2002). According to these studies, cultural characteristics of the four brown rot species are summarised in Table 4.

Table 4 Cultural characteristics of the brown rot fungi of fruit crops

\begin{tabular}{|c|c|c|}
\hline \multicolumn{3}{|c|}{ Colonies on PDA $\left(22{ }^{\circ} \mathrm{C}, 12 \mathrm{~h}\right.$ light $/ 2 \mathrm{~h}$ dark regime $)$} \\
\hline M. fructicola & \multicolumn{2}{|c|}{$\begin{array}{l}\text { growth rate high; sporulation intense (also continuous in } \\
\text { darkness); colour of sporogenous tissue, hazel/isabelline } \\
\text { (Rayner, 1970) }\end{array}$} \\
\hline M. laxa & \multicolumn{2}{|c|}{$\begin{array}{l}\text { growth rate low, renewed outgrowth of mycelium at the } \\
\text { edge of the colony taking place after growth is checked } \\
\text { temporarily (resetting, i.e. mycelium in distinct layers on top } \\
\text { of each) (Corazza et al., 1999); sporulation sparse, colour of } \\
\text { sporogenous tissue, hazel/isabelline (Rayner, 1970) }\end{array}$} \\
\hline M. fructigena & \multicolumn{2}{|c|}{$\begin{array}{l}\text { growth rate low-moderate; sporulation sparse, on distinct } \\
\text { tufts/rings of aerial mycelium, colour of sporogenous } \\
\text { tissue, buff/pale luteous (Rayner, 1970) }\end{array}$} \\
\hline M. polystroma & \multicolumn{2}{|c|}{$\begin{array}{l}\text { growth rate moderate; sporulation sparse; intense } \\
\text { formation of black, stromatal plates initiated after 10-12 } \\
\text { days incubation, colour of sporogenous tissue, buff/pale } \\
\text { luteous (Rayner, 1970) }\end{array}$} \\
\hline \multicolumn{3}{|c|}{ Conidial dimensions (mean and range) ${ }^{a}$} \\
\hline M. fructicola & $13.1 \times 9.1 \mu \mathrm{m}(8)^{\mathrm{b}}$ & $12.4-14.4 \times 8.1-9.9 \mu \mathrm{m}$ \\
\hline M. laxa & $12.0 \times 8.7 \mu \mathrm{m}(4)$ & $11.2-12.8 \times 8.2-9.3 \mu \mathrm{m}$ \\
\hline M. fructigena & $19.2 \times 11.3 \mu \mathrm{m}(6)$ & $17.7-20.6 \times 10.3-12.3 \mu \mathrm{m}$ \\
\hline M. polystroma & $15.9 \times 9.8 \mu \mathrm{m}(6)$ & $12.8-17.1 \times 8.8-10.7 \mu \mathrm{m}$ \\
\hline \multicolumn{3}{|c|}{ Germ tube morphologyc } \\
\hline M. fructicola & \multicolumn{2}{|c|}{ long, straight, $750-900 \mu \mathrm{m}$, one germ tube per conidium } \\
\hline M. laxa & \multicolumn{2}{|c|}{ short, twisted, $150-350 \mu \mathrm{m}$, one germ tube per conidium } \\
\hline M. fructigena & \multicolumn{2}{|c|}{$\begin{array}{l}\text { long, straight, } 600-900 \mu \mathrm{m} \text {, often two germ tubes per } \\
\text { conidium }\end{array}$} \\
\hline M. polystroma & \multicolumn{2}{|c|}{$\begin{array}{l}\text { long, straight, } 700-1000 \mu \mathrm{m} \text {, often two germ tubes per } \\
\text { conidium }\end{array}$} \\
\hline
\end{tabular}

a Conidia grown on $\mathrm{CHA}$ at $22^{\circ} \mathrm{C}$ under NUV light.

b 35 conidia measured per isolate in distilled water, number of isolates in parentheses.

${ }^{\mathrm{c}}$ after $18 \mathrm{~h}$ at $22^{\circ} \mathrm{C}$ on water agar plates.

(adapted from Van Leeuwen et al., 2002)

\section{Acknowledgements} s.

The study was partly supported by a János Bolyai Research Fellowship and the Hungarian Scientific Research Fund (OTKA F043503). 


\section{References}

Aderhold, R., \& Ruhland, W. (1905): Zur Kenntnis der Obstbaum-Sklerotinien. Arbeit. Biol. Abt. Land- \& Forstw. Gesundheitsamte 4: 427-442.

Batra,'L. R. (1979): First authenticated North American record of Monilinia fructigena, with notes on related species. Mycotaxon 8: 476-484.

Batra, L. R. (1988): Disjunctors in Monilinia (Discomycetidae: Sclerotiniaceae) and their significance in classification. Mycologia 80: 660-664.

Batra, L. R. (1991): World species of Monilinia (Fungi): Their ecology, biosystematics and control. Mycologia Memoir No. 16, J. Cramer, Berlin, 246 pp.

Batra, L. R. \& Harada, Y. (1986): A field record of apothecia of Monilinia fructigena in Japan and its significance. Mycologia 78: 913-917.

Benedek, P., Nyéki, J. \& Vályi, I. (1990): Csonthéjas gyümölcsfajták érzékenysége a fontosabb kórokozókkal és kártevốkkel szemben - a fajtaspecifikus növényvédelmi technológia kidolgozása. Növényvédelem 26: 12-31.

Benedek, P., Szabó, Z., Soltész, M., Nyéki, J. \& Kovács, J. (1993): Fruit varieties, plant disease susceptibility, pest control and cultivar improvement. Hungarian Agricultural Research 2(2): 4-10. Berrie, A. M. (1989): Storage rots of apple and pear in South East England 1980-88: incidence and fungicide resistance. In: Gessler B. K. ed. IOBC Bulletin, Vol. II. Integrated control of pome fruit diseases. Locarno, Switzerland: IOBC, 229-239.

Boesewinkel, H. J. \& Corbin, J. B. (1970): Inoculum sources for Monilinia fructicola in Ontario peach Orchards. Canadian Journal of Plant Pathology 7: 302-307.

Bonorden, H. F. (1851): Handbuch der allgemeinen Mykologie, p. 76, Stuttgart

Byrde, R. J. W. \& Willetts, H. J. (1977): The brown rot fungi of fruit. Their biology and control. Pergamon Press, Oxford, 171 pp. CABI/EPPO (1997): Quarantine pests for Europe. Wallingford, UK: CABI International.

CABI/EPPO (1998): Distribution maps of quarantine pests for Europe. Wallingford, UK: CABI International.

Calonge, F. D., Fielding, A. H. Byrde, R. J. W. \& Akinrefon, O. A. (1969): Changes in ultrastructure following fungal invasion and the possible relevance of extracellular enzymes. Journal of Experimental Botany 20: 350-357.

Cation, D., Dunegan, J. C. \& Kephart, J. (1949): The occurrence of Monilinia laxa in Michigan. Plant Disease Reporter 33: 96.

Chang, L. W. H. (1986): Pests not known to occur in the United States or of limited distribution no. 76: a fruit brown rot. Hyattsville, MD, USA: APHIS-PPQ/USDA.

CMI (1991): Distribution maps of plant diseases no. 50. Wallinford, UK: CAB Interantional.

Conel, J. L. (1914): A study of brown-rot fungus in the vicinity of Champaign and Urbana, Illionis. Phytopathology 4: 93-101.

Corazza L, Cook R. T. Lange, C. R. Van Kesteren, H. A., Melgarejo, P., Brown, A. \& Nazare-Pereira A. (1999): Development of diagnostic methods and a rapid field kit for monitoring Monilinia brown rot of stone and pome fruit, especially M. fructicola. EU-FAIR 95-0725 report, Fourth Framework Programme. Brussels, Belgium: European Union.

Croxall, H. E., Collingwood, C. A. \& Jenkins, J. E. E. (1951): Obsercation on brown rot (Sclerotinia fructigena) of apples in relation to injury caused by earwigs (Forficula auricularia). Annals of Applied Biology 38: 833-843.
Drummond, R. (1934): Notes on the wither-tip disease of plums caused by Sclerotinia cinerea and on the blackening of apples caused by Sclerotinia fructigena. Journal of Pomology 12: 105-109. Dunegan, J. C. (1953): Brown rot of peach. In Plant diseases 64888. USDA Agricultural Yearbook.

Ehrenberg, C. G. (1818): Sylvae mycologicae Ber pp. 22. (cited in Byrde \& Willetts, 1977)

English, H., Moller, W. J. \& Nome, S. F. (1967): New records of fungus diseases of fruit crops in Chile. Plant Disease Reporter 51: 212-214.

English, H., Pinto, de Torres, A. \& Kirk, J. (1969): Recocimieto de especies del genero Monilinia en frutales de carozo y en membrillo de flor en Chile. Agricultural Technology 29: 54-59.

Evans, A. W. \& Owens, C. E. (1941): Incidence of Sclerotinia fructicola and S. laxa in sweet cherries in Oregon. Phytopathology 31: 469-471.

Ezekiel, W. N. (1921): Some factors affecting the production of apothecia of Sclerotinia cinerea. Phytopathology 11: 495-499.

Ezekiel, W. N. (1924): Fruit rotting Sclerotinias. II. The American brown-rot fungi. Bull. Md agric. Exp, Sta., 271: 87-142.

Falconi, G. J. \& Mendegen, D. H. (1994): Epiphytic fungi on apple leaves and their value for control of the post-harvest pathogens Botrytis cinerea, Monilinia fructigena and Penicillium expansum. Journal of Plant Disease and Protection 101(1): 38-47. Free, S. J., Holtz, B. A. \& Michailides, T. J. (1996): Mating behavior in field populations of Monilinia fructicola. Mycologia 88: 208-211.

Fröster, H. \& Adaskeveg, J. E. (2000): Early brown rot infection in sweet cherry fruit are detected by Monilinia-specific DNA primers. Phytopathology 90: 171-178.

Fulton, C. E., Van Leeuwen, G. C. M. \& Brown, A. E. (1999): Use of SSU rDNA group-I intron to distinguish Monilinia fructicola from $M$. laxa and $M$. fructigena. FEMS Microbiology Letters 157: 307-312.

Fulton, C. E., \& Brown, A. E. (1997): Use of SSU rDNA groupI intron to distinguish Monilinia fructicola from $M$. laxa and $M$. fructigena. FEMS Microbiology Letters 157: 307-312.

Glits, M. (2000): Alma. In Glits, M. \& Folk, Gy. (eds.): Kertészeti növénykórtan. Mezôgazda Kiadó, Budapest. 167-189.

Gupta, G. K. \& Byrde, R. J. W. (1988): Monilinia laxa associated with blossom wilt of apricot and almond in Himachal Pradesh, India. Plant Pathology 37: 591-593.

Hall, M. P. (1933): An analysis of the factors controlling the growth form of certain fungi, with especial reference to Sclerotinia (Monilia) fructigena. Annals of Botany 47: 543-578.

Harada, Y. (1977): Studies on the Japanese species of Monilinia (Sclerotiniaceae). Bulletin of Faculty of Agriculture Hirosaki University 27: 30-109.

Harrison, T. H. (1933): Brown rot of fruits and associated diseases of deciduous fruit trees. J. Proc. R. Soc. N.S.W. 67: 132-177.

Hawker, L. E. (1957): The Phisiology of Reproduction in fungi. Cambridge Press. UK. pp. 19-23.

Heuberger, J. W. (1934): Fruit-rotting sclerotias. IV: A cytological study of Sclerotinia fructicola (Wint.) Rehm. University of Maryland Agricultural Experimental Station Bulletin 371: 167-189.

Hewitt, W. B. \& Leach, L. D. (1939): Brown-rot Sclerotinias occurring in California and their distribution on stone fruits. Phytopathology 29: 337-351.

Honey, E. E. (1936): North American species of Monilinia. I. Ocurrence, grouping, and life-histories. American Journal of Botany 23: 100-106. 
Honey, E.E. (1928): The monilioid species of Sclerotinia. Mycologia 20: 127-157.

Hughes, K. J. D., Fulton, C. E., McReynold, D. \& Lange, C. R. (2000): Development of new PCR primers for identification of Monilinia species. EPPO Conferences on diagnostic techniques for plant pests, 1-4 February 2000, Wageningen, the Netherlands, 54. (Abstract)

Humprey, J. E. (1893): On Monilia fructigena. Bot Gaz (Crawfordswille). 18: 85-93.

Ioos, R. \& Frey P. (2000): Genomic variation within Monilia laxa. $M$. fructigena and $M$. fructicola, and application to species identification by PCR. EPPO Conferences on diagnostic techniques for plant pests, 1-4 February 2000, Wageningen, the Netherlands. 52. (Abstract)

Jackson, H. S. (1915): Notes on plant diseases: Pear canker. Monilia sp. In: Oregon Agricultural Experimental Station Bien. Crop and Pest Report 1913-1914, 271-272.

Jenkins, P. T. (1965a): Sclerotinia laxa Aderh. \& Ruhl.: a cause of brown rot of stone fruits not previously recorded in Australia. Australian Journal of Agricultural Research 16: 141-144.

Jenkins, P. T. (1965b): The dispersal of conidia of Sclerotina fructicola (Wint.) Rehm under field conditions. Australian Journal of Agricultural Research 16: 937-945.

Johansen, G. (1945): Monilinia fructigena (Aderh. \& Ruhl.) Honey in Denmark. Fresia 3:111-114.

Jones A. L. \& Sutton, T. B. (1984): Diseases of tree fruits. N. Central Reg. Ext. Publ. 45. Coop. Ext. Serv. Mich. State Univ. 59 pp. Kable, P. F. \& Parker, K. G. (1963): The occurrence of the imperfect stage of Monilinia laxa on Prunus cerasus var. austeria in New York State. Plant Disease Reporter 47: 1104.

Kable, P. F. (1965): The fruit peduncle as an important overwintering site of Monilinia fructicola in the Murrumbidgee Irrigation Areas. Australian Journal of Experimental Agriculture, Animal Husbandry 5: 172-175.

Keitt, G. W., Duain Moore, J., Calavan, E. C. \& Shay, J. R. (1943): Occurrence of the imperfect stage of Sclerotinia laxa on Prunus cerasus in Wisconsin. Phytopathology 33: 1212-1213.

Kunze, G. \& Schmidt, J. C. (1817): Mycologische Hefte 1: 80. (cited in Byrde \& Willetts, 1977)

Lack, H. (1989): The spread of apple brown rot (Monilinia fructigena) by insects. Annals of Applied Biology 115(2): 221-227. Ma, Z., Luo, Y. \& Michailides, T.J. (2003): Nested PCR assays for detection of Monilinia fructicola in stone fruit orchards and Botryosphaeria dothidea from pistachios in California. Journal of Phytopathology 151 (6): 312-322.

Michailides, T. J. \& Morgan, D. P. (1997): Influence of fruit-tofruit contact on the susceptibility of French prune to infection by Monilinia fructicola. Plant Disease 81: 1416-1424.

Mirocha, C. J. \& Wilson, E. E. (1961): Hull rot diseases of almonds. Phytopathology 51: 843-847.

Mix, A. J. (1930): A blight of flowering almond, Prunus glandulosa Thunb. Phytopathology 20: 265.

Moore, M. H. (1950): Brown rot of apples: fungicide trials and studies of the relative importance of different wound-agents. Journal of Horticultural Science 25: 225-234.

Najim, I. \& Turian, G. (1979): Ultrastructure de l'hyphe vegetatif de Slcerotinia fructigena. Canadian Journal of Botany 57: 1299-1305.

Norton, J. S. B. \& Ezekiel, W. N. (1924): The name of the American brown-rot Sclerotinia. Phytopathology 14: 31-32.

Norton, J. S. B. (1902): Sclerotinia fructigena. Transaction Academy Science St. Luis 12: 91-97.
Norton, J. B. S., Ezekiel, W. N. \& Jehle, R.A. (1923): Fruitrotting Sclerotinias I. Apothecia of the brown-rot fungus. Maryland Agricultural Experimental Station Bulletin 256: 1-32.

OEPP/EPPO (1992): Quarantine pests for Europe, Monilinid fructicola, p. 530-535.

Ogawa, J. M. \& English, H. (1960): Relative pathogenicity of two brown rot fungi, Sclerotinia laxa and Sclerotinia fructicola, on twigs and blossoms. Phytopathology 50: 550-558.

Ogawa, J. M. English, H., Moller, W. J., Manji, B. T., Rough, D. \& Koike, S. T. (1980): Brown rot of stone fruits. Calif. Univ. Div. Agric. Sci. Leaf. 2206, 7.

Ogawa, J. M. \& English, W. H. (1954): Means of differentiating atypical isolates of Sclerotinia laxa and $S$. fructicola. Phytopathology 44: 500 .

Ogawa, J. M., English, W. H. \& Wilson, E. E. (1954): Survey for brown rot of stone fruits in California. Plant Dis. Reptr. 38: 254-257. Peck, C. H. (1881): Report of New York State Museum of Natural History 34: 34-36. (cited in Byrde \& Willetts, 1977)

Penrose, L. J., Tarran, J. \& Wong, A. L. (1976): First record of Sclerotinia laxa Aderh. \& Ruhl. in New South Wales: differentiation from $S$. fructicola (Wint.) Rehm. by cultural characteristics and electrophoresis. Australian Journal of Agricultural research 27: 547-556.

Persoon, C.H. (1796): Observationes Mycologicae, p. 26 (cited in Byrde \& Willetts, 1977)

Pring, R. J., Byrde, R. J. W. \& Willetts, H. J. (1981): An ultrastructural study of the infection of pear fruit by Monilinia fructigena. Physiol. Plant Pathology 19: 1-9.

Rayner, R. W. (1970): A mycological colour chart. Commonwealth mycological institute, Kew, Surrey, England.

Ridgway, R. (1912): Colour standards and colour nomenclature. 111 Pls., 43. p. Washington, D.C. USA.

Roberts, J. W. \& Dunegan, J. C. (1924): Fungus causing the common brown rot of fruits in America. Journal of Agricultural Research 28: 955-960.

Schlagbauer, H. E. \& Holz, G. (1987): Blossom blight and brown rot of stone fruit caused by Monilinia laxa in the Cape province of South Africa. Phytophylactica 19: 513-514.

Schlagbauer, H. E. \& Holz, G. (1990): Infection and colonization of plum blossoms by Monilinia laxa. Phytophylactica 22: 419-422. Schröter C. J. (1893): Sclerotinia. In: (ed.): Cohn F. Kryptogamen-Flora von Schleisen vol 3, part 2. Breslau, Germany: J. U. Kern's Verlag.

Sharma, R. L. \& Kaul, J. L. (1987): Blossom blight and fruit rot of apple. Indian Journal of Plant Pathology 5: 205-206.

Shima, Y. (1936): Studies on the young fruit-rot of apple tree. Journal of Faculty of Agriculture Hokkaido University 39: 143-149. Sonoda, R. M., Ogawa, J. M. \& Manji, B. T. (1982a): Use of interactions of cultures to distinguish Monilinia laxa from $M$ fructicola. Plant Disease 66: 325-326.

Sonoda, R. M., Ogawa, J. M., Esser, T. E. \& Manji, B. T, (1982b): Mycelial interaction zones among single ascospore isolates of Monilinia fructicola. Mycologia 74: 681-683.

Sutton, T. B. \& Clayton, C. N. (1972): Role and survival of Monilinia fructicola in blighted peach branches. Phytopathology 62: 1369-1373.

Szabó, Z. \& Nyéki, J. (1995): A Monilia laxa és a Venturia carpophila súlyosbodó kártétele a szilván. Növényvédelmi fórum 95' Keszthely, Összefoglalók 38.

Tamm, L., Minder, C. E. \& Flückiger, W. (1995): Phenological analysis of brown rot blossom blight of sweet cherry caused by Monilinia laxa. Phytopathology 85: 401-408. 
Terui, M. \& Harada, Y. (1966): On the brown rot fungus Monilinia fructicola of fruit trees in Japan. Annals of the Phytopathological Society of Japan 32: 291-294.

Van Leeuwen, G. C. M. \& Van Kesteren, H. A. (1998): Delineation of the three brown rot fungi of fruit crops (Monilinia spp.) on the basis of quatitative characteristics. Canadian Journal of Botany 76: 2042-2050.

Van Leeuwen, G. C. M., Stein, A., Holb, I. \& Jeger, M. J. (2000): Yield loss caused by Monilia fructigena (Aderh. \& Ruhl.) Honey, and spatio-temporal dynamics of disease development. European Journal of Plant Pathology 106: 519-528.

Van Leeuwen, G. C. M., Baayern, R. P., Holb, I. J. \& Jeger, M.J. (2002): Distinction of the Asiatic brown rot fungus Monilia polystroma sp. nov. from Monilia fructigena. Mycological Research 106: 444 451.

Wallroth, F. G. (1933): Flora cryptogamia Germaniae. Nürnberg, Germany 11: 182-183. (cited in Byrde \& Willetts, 1977)

Weaver, L. O. (1950): Effect of temperature and relative humidity on occurrence of blossom blight of stone fruits. Phytopathology 40 : 1136-1153.

Whetzel, H. H. (1945): A synopsis of the genera and species of the Sclerotiniaceae, a family of stromata inoperculate Discomycete. Mycologia 37: 648-714.

Wilcox, W. F. (1989): Influence of environment and inoculum density on the incidence of brown rot blossom blight of sour cherry. Phytopathology 79: 530-534.

Willetts, H. J. \& Bullock, S. (1993): Cytology, histology and histochemistry of fruit infection by Monilinia species. In A. R. Biggs (eds.) Handbook of cytology, Histology and Histochemistry of Fruit Tree Diseases pp. 113-136. CRC Press: Boca Raton.

Willetts, H. J. (1968a): Factors influencing the production of stromata and microconidia by Sclerotinia fructicola (Wint.)Rehm. Annals of Botany 32: 219-232.

Willetts, H. J. (1968b): Stromatal rind formation in the brown rot fungi. Journal of General Microbiology 52: 271-273.

Willetts, H. J. (1968c): The development of stromata of Sclerotinia fructicola and related species I. In culture. Transaction for British Mycological Society 51: 625-632.

Willetts, H. J. (1968d): The development of stromata of Sclerotinia fructicola and related species II. In fruits. Transaction for British Mycological Society 51: 633-642.
Willetts, H. J. (1969a): Cultural characteristics of the brown rot fungi (Sclerotinia spp.). Mycologia 61: 332-339.

Willetts, H. J. (1969b): The development of stromata of Sclerotinia fructicola and related species III. Further observations and conclusions. Transaction for British Mycological Society 52: 309-314.

Willetts, H. J. (1997): Morphology, development and evolution of stromata/sclerotia and macroconidia of the Sclerotiniaceae. Mycological Research 101(8): 939-952.

Willetts, H. J. \& Calonge, F. D. (1969): Spore development in the brown rot fungi (Sclerotinia spp.). New Phytologist 68: 123-131. Willetts, H. J. \& Harada, Y. (1984): A review of apothecial production by Monilinia fungi in Japan. Mycologia 76: 314-325.

Willetts, H. J., Byrde, R. J. W., Fielding, A. H. \& Wong, A. L. (1977): The taxonomy of the brown rot fungi (Monilinia spp.) related to their extracellular cell wall-degrading enzymes. Journal of General Microbiology 103: 77-83.

Winter, G. (1883): Uber einege Nordamerikanische Pilz. Hedwigia 22: 67-72, 129-131.

Wormald, H. (1918): A "wither tip" of plum trees. Annals of Applied Biology 5: 28-59.

Wormald, H. (1920): The 'brown rot' diseases of fruit trees, with special reference to two biologic forms of Monilia cinerea Bon. II. Ann. Bot., London, 34: 143-171.

Wormald, H. (1927): Further studies of the brown-rot fungi. II. A contribution to our knowledge of the distribution of the species of Sclerotinia causing brown-rot. Annals of Botany 41: 287-299.

Wormald, H. (1954): The brown rot disease of fruit trees. Ministry of Agriculture, Fisheries and Food, Technical Bulletin no. 3, London Woronin, M. (1900): Über Sclerotinia cinerea und Sclerotinia fructigena. Mem. Acad. Imp. Sci. St. Petersbourg, VIII: 10(5): $1-37$.

Xu, X. M. \& Robinson, J. D. (2000): Edidemiology of brown rot (Monilinia fructigena) on apple: infection of fruits by conidia. Plant Pathology 49 (2): 201-206.

Zehr, E. I. (1985): Importance and control of blossom blight in the southeastern United States. New York State Agricultural Experimental Station Spec. Report 55: 2-4. 